\title{
3-O-Methylrhamnose: Identification and Distribution in Catellatospora Species and Related Actinomycetes
}

\author{
KOZO ASANO, ${ }^{1 *}$ HIROSHI SANO, ${ }^{2}$ IZUMI MASUNAGA, ${ }^{3}$ AND ISAO KAWAMOTO ${ }^{2}$ \\ Foods and Liquors Research Laboratories, Kyowa Hakko Kogyo Co., Ltd., 4041, Ami-Machi, Inashiki-Gun, Ibaraki, \\ 300-03 Japan ${ }^{1}$; Tokyo Research Laboratories, 3-6-6 Asahi-Machi, Machida 194, Tokyo, Japan ${ }^{2}$; and Miles-Kyowa Co., \\ Ltd. 1-2-3 Kita-Aoyama, Minatoku, 107 Tokyo, Japan ${ }^{3}$
}

\begin{abstract}
3-O-methylrhamnose was found in cell walls of Catellatospora ferruginea. This sugar was purified and identified by proton and ${ }^{13} \mathrm{C}$ nuclear magnetic resonance and mass spectroscopy, using the acetylation method. It is localized in the cell wall fraction and occurs at a constant ratio among the cell wall sugars when various carbon sources are used for growth. 3- $O$-methylrhamnose was found in nine strains of Catellatospora species containing MK-10 as the major menaquinone, but not in nine strains containing MK-9. Among 22 type strains of genera related to Catellatospora (Actinoplanes, Amorphosphorangium, Ampullariella, Dactylosporangium, Micromonospora, Glycomyces, and “Catenuloplanes"), 4 strains contained only trace quantities, and the remainder contained none. Thus, we propose that 3-O-methylrhamnose is a key sugar in the chemotaxonomy of the genes Catellatospora.
\end{abstract}

Cell wall sugar composition is one of the important keys for chemotaxonomy of actinomycetes. We described previously an unknown sugar which gave a brown color upon reaction with aniline phthalate on paper chromatograms of the hydrolysate of Catellatospora ferruginea $6257-\mathrm{C}^{\mathrm{T}}(\mathrm{T}=$ type strain) (2).

The members of Catellatospora, a genus belonging to the Actinomycetales, form chains of nonmotile spores from their vegetative hyphae on the surfaces of agar media, lack true aerial mycelia, and have type II cell wall amino acids (13) (meso- and 3-hydroxy diaminopimelic acid and glycine), a glycolyl type of cell wall sugar (25), a pattern D whole-cell sugar (xylose and arabinose) (14), and a type PII phospholipid pattern (phosphatidylethanolamine) $(2,15)$.

In this paper, we describe the isolation and purification of an unknown sugar from cell walls of Catellatospora ferrugi- significance of this sugar in the genus Catellatospora is discussed.

\section{MATERIALS AND METHODS}

Bacterial strains and culture conditions. The strains used in this study were 3 type strains and 15 isolates belonging to the genus Catellatospora, 20 type strains of species in related genera in the actinoplanate group (7), and 2 additional type strains of species in the genera Glycomyces and "Catenuloplanes." All of these strains have a type D whole-cell sugar pattern, containing xylose and arabinose as diagnostic sugars (13). The members of Catellatospora and genera of the actinoplanate group have type II cell wall amino acids (meso- and 3-hydroxy diaminopimelic acid and glycine) and a type PII phospholipid pattern (phosphatidylethanolamine).

TABLE $1 . R_{f}$ values of the unknown sugar and rhamnose in various solvent systems

\begin{tabular}{|c|c|c|c|}
\hline \multirow[b]{2}{*}{ Solvent system } & \multirow[b]{2}{*}{ Technique $^{a}$} & \multicolumn{2}{|c|}{$R_{f}$ values } \\
\hline & & $\begin{array}{l}\text { Unknown } \\
\text { sugar }\end{array}$ & Rhamnose \\
\hline iso-Propanol-chloroform $(1: 1, \mathrm{vol} / \mathrm{vol})$ & Cellulose TLC & 0.65 & 0.30 \\
\hline$n$-Butanol-acetic acid-water $(4: 1: 1, \mathrm{vol} / \mathrm{vol})$ & Cellulose TLC & 0.57 & 0.51 \\
\hline$n$-Butanol-pyridine-water-toluene $(10: 6: 6: 1, \mathrm{vol} / \mathrm{vol})$ & Paper chromatography & 0.59 & 0.39 \\
\hline iso-Propanol-chloroform-ammonia water $(10: 10: 1$, vol/vol $)$ & Silica gel TLC & 0.22 & 0.06 \\
\hline
\end{tabular}

${ }^{a}$ TLC, Thin-layer chromatography.

nea $6257-\mathrm{C}^{\mathrm{T}}$ by acid hydrolysis, solvent extraction, and preparative chromatography. We identified this sugar as 3 - $O$-methylrhamnose by proton and ${ }^{13} \mathrm{C}$ nuclear magnetic resonance (NMR) and mass spectrometry. We were interested in the significance of the distribution of this sugar, and we examined its presence among 18 strains of Catellatospora species and 22 type strains of related genera by using high-performance liquid chromatography. The taxonomic

\footnotetext{
* Corresponding author.
}

On the other hand, the members of the genus Glycomyces have type II cell wall amino acids but a type PI phospholipid pattern. The members of the unapproved genus "Catenuloplanes" are devoid of diaminopimelic acid in their peptidoglycans (W. D. Celmer, W. P. Cullen, L. H. Huang, J. R. Oscarson, R. Shibakawa, and J. Tone, U.S. patent $4,287,182$, September 1981).

List of strains used in this study. We used the following strains belonging to the genus Catellatospora: Catellatospora citrea $6183-\mathrm{E}^{\mathrm{T}}$ (= IFO 14495 $\left.{ }^{\mathrm{T}}\right)(2), 6188-\mathrm{B}, 6198-\mathrm{A}$, 6198-B, 6252-E, and 6479-A, Catellatospora citrea subsp. methionotrophica $6257-\mathrm{B}^{\mathrm{T}}\left(=\mathrm{IFO} 14553^{\mathrm{T}}\right)(3)$ and $6498-\mathrm{D}$ 
TABLE 2. ${ }^{1} \mathrm{H}$ NMR data for the unknown sugar and its triacetate ${ }^{a}$

\begin{tabular}{|c|c|c|c|c|}
\hline \multirow{2}{*}{ Signal } & \multicolumn{2}{|c|}{ Unknown sugar } & \multicolumn{2}{|c|}{ Unknown sugar triacetate } \\
\hline & $\alpha$ & $\beta$ & $\alpha$ & $\beta$ \\
\hline $\mathrm{H}-1$ & $5.18(\mathrm{~d}, 1.9 \mathrm{~Hz})$ & 4.87 (bs) & $6.03(\mathrm{~d}, 2.0 \mathrm{~Hz})$ & $5.76(\mathrm{~d}, 1.1 \mathrm{~Hz})$ \\
\hline $\mathrm{H}-2$ & $4.20(\mathrm{dd}, 2.0,2.0 \mathrm{~Hz})$ & $4.22(\mathrm{bd}, 3.0 \mathrm{~Hz})$ & $5.32(\mathrm{dd}, 2.0,3.4 \mathrm{~Hz})$ & $5.58(\mathrm{dd}, 1.1,3.2 \mathrm{~Hz})$ \\
\hline $\mathrm{H}-3$ & $3.45 \simeq 3.55(\mathrm{~m})^{b}$ & $3.33(\mathrm{dd}, 3.1,9.5 \mathrm{~Hz})$ & $3.61(\mathrm{dd}, 3.4,9.8 \mathrm{~Hz})$ & $3.40(\mathrm{dd}, 3.2,9.8 \mathrm{~Hz})$ \\
\hline $\mathrm{H}-4$ & $\int .45-5.53(\mathrm{III})$ & $3340 \approx 350(\mathrm{~m})^{b}$ & $5.02(\mathrm{dd}, 9.8,9.8 \mathrm{~Hz})$ & $4.97(\mathrm{dd}, 9.8,9.8 \mathrm{~Hz})$ \\
\hline $\mathrm{H}-5$ & $3.91(\mathrm{dq}, 6.4,9.3 \mathrm{~Hz})$ & $3.40 \simeq 3.50(\mathrm{~m})$ & $3.84(\mathrm{dq}, 6.2,9.8 \mathrm{~Hz})$ & $3.58(\mathrm{dq}, 6.2,9.8 \mathrm{~Hz})$ \\
\hline $6-\mathrm{CH}_{3}$ & $1.29(\mathrm{~d}, 6.4 \mathrm{~Hz})$ & $1.31(\mathrm{~d})$ & $1.21(\mathrm{~d}, 6.2 \mathrm{~Hz})$ & $1.27(\mathrm{~d}, 6.2 \mathrm{~Hz})$ \\
\hline $3-\mathrm{OCH}_{3}$ & $3.460(\mathrm{~s})$ & 3.464 & $3.37(\mathrm{~s})$ & $3.35(\mathrm{~s})$ \\
\hline OAc & & & 2.104 & 2.098 \\
\hline & & & 2.142 & 2.142 \\
\hline & & & 2.157 & 2.196 \\
\hline
\end{tabular}

${ }^{a}$ The values are $\delta$ values (in parts per million) in $\mathrm{D}_{2} \mathrm{O}$ for the unknown sugar and in $\mathrm{CDCl}_{3}$ for its triacetate.

${ }^{b}$ The coupling constants could not be obtained, because of overlapping of the signals of $\alpha(\mathrm{H}-3, \mathrm{H}-4)$ and $\beta(\mathrm{H}-4, \mathrm{H}-5)$.

(3); Catellatospora ferruginea $6257-\mathrm{C}^{\mathrm{T}}\left(=\mathrm{IFO} 14496^{\mathrm{T}}\right)(2)$, 6168-B, 6183-F, 6248-A, 6423-A, 6432-C, 6464-O, and 6479$\mathrm{B}$; and Catellatospora sp. strains 6393-C and 6420-P. Strains 6188-B, 6198-A, 6198-B, 6252-E, 6479-A, 6464-O, 6479B, 6393-C, and 6420-P were novel isolates from soil samples collected at different geographical sites in Japan.

We also used the following strains belonging to actinoplanate genera: Actinoplanes braziliensis ATCC $25844^{\mathrm{T}}$, Actinoplanes caeruleus. NRRL $5325^{\mathrm{T}}$, Actinoplanes deccanensis ATCC $21983^{\mathrm{T}}$, Actinoplanes ferrugineus $\mathrm{JCM} 3277^{\mathrm{T}}$ (= ATCC $29868^{\mathrm{T}}$ ), Actinoplanes italicus ATCC $27366^{\mathrm{T}}$, Actinoplanes philippinensis NRRL $5462^{\mathrm{T}}$, Actinoplanes rectilineatus JCM $3194^{\mathrm{T}}$ (= ATCC 29234 ${ }^{\mathrm{T}}$ ), Amorphosporangium auranticolor ATCC $15330^{\mathrm{T}}$, Amorphosporangium globisporum JCM $3186^{\mathbf{T}}$ (= ATCC $23056^{\mathrm{T}}$ ), Ampullariella lobata $\mathrm{JCM} 3061^{\mathrm{T}}\left(=\mathrm{ATCC} 15350^{\mathrm{T}}\right)$, Ampullariella degitata ATCC $15349^{\mathrm{T}}$, Dactylosporangium aurantiacum ATCC $23491^{\mathrm{T}}$, Dactylosporangium matsuzakiense ATCC $31570^{\mathrm{T}}$, Dactylosporangium thailandense JCM $3084^{\mathrm{T}}$ (= ATCC $23490^{\mathrm{T}}$ ), Micromonospora carbonacea subsp. carbonacea NRRL $2972^{\mathrm{T}}$ (= ATCC $\left.27114^{\mathrm{T}}\right)$, Micromonospora chalcea subsp. chalcea ATCC $12452^{\mathrm{T}}$, Micromonospora echinospora subsp. pallida NRRL $2996^{\mathrm{T}}$ (= ATCC $15838^{\mathrm{T}}$ ), Micromonospora halophytica subsp. halophytica ATCC $27596^{\mathrm{T}}$, Micromonospora inositola ATCC $21773^{\mathrm{T}}$, and Micromonospora purpureochromogenes ATCC $27007^{\mathrm{T}}$.

The other related strains used were Glycomyces harbinensis NRRL $15337^{\mathrm{T}}$ and "Catenuloplanes japonicus" ATCC 31637.

Preparation of cell walls and chemical analysis. For cell wall preparation the organisms were cultured in a liquid medium containing $1 \%$ glucose, $1 \%$ soluble starch, $0.5 \%$ yeast extract, $0.5 \%$ polypeptone, $0.2 \%$ beef extract, and $0.02 \%$ calcium bicarbonate (final $\mathrm{pH} 6.8$ ) and incubated at $30^{\circ} \mathrm{C}$ for 2 to 4 days. Glucose and soluble starch were replaced by other carbon sources to obtain cell walls under different culture conditions. Harvested cells were washed twice with saline, sonicated, and centrifuged at $10,000 \times g$ for $30 \mathrm{~min}$. The debris was defatted twice with chloroformmethanol $(3: 1, \mathrm{vol} / \mathrm{vol})$, boiled with $4 \%$ sodium dodecyl sulfate for $1 \mathrm{~h}$, centrifuged at $100,000 \times g$ for $30 \mathrm{~min}$, and then washed four times with hot distilled water with centrifugation. The resulting semitransparent pellets were lyophilized and then used as purified cell wall preparations.

Reducing sugars were determined by high-performance liquid chromatography as described previously (2).

${ }^{1} \mathrm{H}$ and ${ }^{13} \mathrm{C}$ NMR spectra were recorded with a Bruker model AM400 spectrometer, using tetramethylsilane $(\delta=0$ ppm) as an internal standard.
The unknown sugar was acetylated with acetic anhydride by using pyridine as a catalyst at room temperature for $15 \mathrm{~h}$. Methanol was added to the reaction mixture, which was stored for $30 \mathrm{~min}$ at room temperature, and then dried in vacuo. The triacetate of the unknown sugar was purified by silica gel column chromatography with a toluene-acetone (9: 1 , vol/vol) solvent system.

\section{RESULTS}

Detection of an unknown sugar. An unknown sugar was detected on cellulose or silica gel thin-layer chromatograms or paper chromatograms of hydrolysates of whole cells and cell walls. The spot of the unknown sugar moved ahead of rhamnose and gave a brown color with the aniline phthalate reagent and a yellowish green color with the anisaldehyde reagent, but did not reacted with ninhydrin or the RydonSmith reagent. $R_{f}$ values in various solvent systems are shown in Table 1 .

Isolation and purification of the unknown sugar. The unknown sugar was isolated and purified from cell walls of Catellatospora ferruginea $6257-\mathrm{C}^{\mathrm{T}}$. It was the least polar among the reducing sugars in the cell walls hydrolysate. This characteristic was used effectively during purification. Purified cell walls $(1.1 \mathrm{~g})$ were hydrolyzed with $1 \mathrm{~N}$ sulfuric acid at $100^{\circ} \mathrm{C}$ for $3.5 \mathrm{~h}$, and this was followed by neutralization with Dowex WGR $\left(\mathrm{OH}^{-}\right.$form) and lyophilization. The resulting material was first extracted with methanol and then

TABLE $3 .{ }^{13} \mathrm{C}$ NMR data for the unknown sugar, its triacetate, and rhamnose ${ }^{a}$

\begin{tabular}{|c|c|c|c|c|c|c|}
\hline \multirow{2}{*}{ Signal } & \multicolumn{2}{|c|}{ Unknown sugar } & \multicolumn{2}{|c|}{ Triacetate } & \multicolumn{2}{|c|}{ Rhamnose $^{b}$} \\
\hline & $\alpha$ & $\beta$ & $\alpha$ & $\beta$ & $\alpha$ & $\beta$ \\
\hline C-1 & 94.85 & 94.45 & 91.16 & 91.26 & 95.0 & 94.6 \\
\hline C-2 & 71.99 & 72.88 & 72.11 & 71.87 & 71.9 & 72.4 \\
\hline C-3 & 80.34 & 72.79 & 76.95 & 79.37 & 71.1 & 73.8 \\
\hline C-4 & 67.39 & 67.89 & 67.06 & 66.68 & 73.3 & 72.9 \\
\hline C-5 & 69.17 & 71.68 & 68.93 & 71.69 & 69.4 & 73.1 \\
\hline $6-\mathrm{CH}_{3}$ & 17.72 & 17.69 & 17.56 & 17.49 & 18.0 & 18.0 \\
\hline $3-\mathrm{OCH}_{3}$ & 57.04 & 56.95 & 57.91 & 57.71 & & \\
\hline $\mathrm{COCH}_{3}$ & \multirow{2}{*}{\multicolumn{6}{|c|}{$\begin{array}{c}(20.06,20.95,20.99[2])^{c} \\
(168.43,168.86,170.00 \\
170.59,170.13)^{d}\end{array}$}} \\
\hline $\mathrm{COCH}_{3}$ & & & & & & \\
\hline
\end{tabular}

"The values are $\delta$ values (in parts per million) in $\mathrm{D}_{2} \mathrm{O}$ for the unknown sugar and in $\mathrm{CDCl}_{3}$ for its triacetate.

$b$ Data from reference 5 .

c These methoxy signals could not be assigned to $\alpha$ or $\beta$.

${ }^{d}$ These carbonyl signals could not be assigned to $\alpha$ or $\beta$. 
TABLE 4. Sugar compositions in fractions from cells of Catellatospora ferruginea $6257-\mathrm{C}^{\mathrm{T}}$

\begin{tabular}{|c|c|c|c|c|c|c|c|c|}
\hline \multirow{2}{*}{ Fraction } & \multicolumn{8}{|c|}{ Amt $(\mu \mathrm{g} / \mathrm{mg})$ of: } \\
\hline & $\begin{array}{l}\text { 3-O-methyl } \\
\text { rhamnose }\end{array}$ & Rhamnose & Ribose & Mannose & Arabinose & Galactose & Xylose & Glucose \\
\hline Whole cells & 12.2 & 5.7 & 7.5 & 24.5 & 3.9 & 4.7 & 13.8 & 18.1 \\
\hline Sonicated cells & & & & & & & & \\
\hline Supernatant & 1.9 & 1.2 & 7.7 & 18.5 & 1.6 & 1.6 & 6.1 & 115.1 \\
\hline Precipitate & 20.6 & 9.9 & 5.5 & 32.2 & 6.2 & 8.0 & 20.7 & 49.8 \\
\hline Cell walls & 39.1 & 22.8 & $\mathrm{ND}^{a}$ & 9.5 & 11.2 & 14.4 & 29.6 & 20.2 \\
\hline
\end{tabular}

${ }^{a} \mathrm{ND}$, Not detected.

evaporated and extracted with chloroform-isopropanol (1:1, $\mathrm{vol} / \mathrm{vol})$. The extract was concentrated and developed on a preparative paper chromatogram with $n$-butanol-ethanolwater (4:1:5, vol/vol, upper phase) as the solvent system. The sugar was detected with aniline phthalate reagent on each edge of the chromatogram; then a band indicated by the spot test was removed, extracted with distilled water, filtered through a membrane filter (pore size, $0.2 \mu \mathrm{m}$ ), and lyophilized. Subsequently silica gel thin-layer chromatography was performed with chloroform-iso-propanol-ammonia water $(10: 10: 1, \mathrm{vol} / \mathrm{vol})$ as the solvent system; the $R_{f}$ value is shown in Table 1 . The sugar detected with the anisaldehyde reagent was removed, extracted with chloroform-isopropa$\mathrm{nol}(1: 1, \mathrm{vol} / \mathrm{vol})$, and concentrated. A white powder of the unknown sugar $(20 \mathrm{mg})$ was obtained.

Identification of the unknown sugar. In the ${ }^{1} \mathrm{H}$ and ${ }^{13} \mathrm{C}$ NMR spectra of the unknown sugar (Tables 2 and 3), one anomeric proton or carbon, four hydroxyl group-bonded tertiary carbons, one methyl, and one methoxyl signal were observed as paired signals. This suggested that the unknown sugar was an anomeric mixture of monodeoxy-mono- $O$ methoxyl six-member sugars. ${ }^{1} \mathrm{H}$ homodecoupling experiments of the unknown sugar and its triacetate, which was prepared by acetylation, revealed the assignments of all protons and their coupling constants. These coupling constants were classified into small coupling constants (2 to 3 $\mathrm{Hz}$ ) in $\mathrm{J}_{1,2}$ and $\mathbf{J}_{2,3}$, but other coupling constants were large ( 9 to $10 \mathrm{~Hz}$ ), showing a manno configuration. The coupling pattern of $\mathrm{H}-5$ showed that the methyl group was bonded to position 5; that is, the unknown sugar was thought to be a mono- $O$-methyl derivative of 6-deoxymannose (rhamnose).

We confirmed that the bonding position of the methoxyl group was in position 3 by a comparison of the compositions of ${ }^{1} \mathrm{H}$ NMR chemical shifts between the unknown sugar and its triacetate. This is because low field shifts of $\mathrm{H}-1, \mathrm{H}-2$, and $\mathrm{H}-4$ were observed in the spectrum of the unknown sugar triacetate.

Thus, the structure of the unknown sugar was determined to be 3-O-methylrhamnose (= acofriose). The secondary- ionization mass spectroscopy spectra of the sugar and its triacetate supported our conclusions concerning the structures of these compounds (data not shown).

Localization of 3-O-methylrhamnose. The localization of 3-O-methylrhamnose in the organism was determined by cell fractionation (Table 4). Glucose, xylose, mannose, and ribose were detected in the hydrolysates of supernatants $(10,000 \times g$ for $30 \mathrm{~min})$ from sonicated cells. These sugars were also components of the cytoplasm, while 3-O-methylrhamnose, rhamnose, arabinose, and galactose were localized in the cell wall fraction. 3-O-methylrhamnose occupied $28.5 \%$ (by weight) of the reducing sugars in the cell walls, but only $1.2 \%$ in the cytoplasm. No ribose was detected in the cell walls.

Constancy of reducing sugar ratio in cell walls. To be taxonomically significant, constancy of the reducing sugar ratio in cell walls must be observed even though cells are grown under different culture conditions. Five different sugars were evaluated as sole carbon sources. Glucose provided the best growth and gave a dry weight of cultured cells of $16.0 \mathrm{mg} / \mathrm{ml}$, followed by galactose, which gave a dry weight of $13.0 \mathrm{mg} / \mathrm{ml}$, arabinose $(9.8 \mathrm{mg} / \mathrm{ml})$, rhamnose $(9.3$ $\mathrm{mg} / \mathrm{ml})$, and xylose $(7.3 \mathrm{mg} / \mathrm{ml})$. Table 5 shows the reducing sugar contents in hydrolysates of sonicated soluble fractions from cells grown on the different carbon sources. The contents varied widely, especially when cells were grown on rhamnose, arabinose, galactose, and glucose. However, in the cell walls the ratios of all of the reducing sugars except glucose were constant (Table 6). Despite different cultural conditions the ratios of 3-O-methylrhamnose, arabinose, and xylose were constant. This result showed that the components of the cell wall polysaccharides of Catellatospora are strictly regulated.

Distribution of 3-O-methylrhamnose in strains of Catellatospora species and related genera. The constant ratio of 3-O-methylrhamnose in cell walls is a characteristic of Catellatospora ferruginea $6257-\mathrm{C}^{\mathrm{T}}$. For chemotaxonomic reasons the distribution of this sugar was determined in

TABLE 5. Sugar contents in hydrolysates of sonic extract soluble fractions from Catellatospora ferruginea $6257-\mathrm{C}^{\mathrm{T}}$ grown on various carbon sources

\begin{tabular}{lcccccrrr}
\hline \multirow{2}{*}{$\begin{array}{l}\text { Carbon } \\
\text { source }\end{array}$} & \multicolumn{7}{c}{ Sugar contents $(\mu \mathrm{g} / \mathrm{mg}$ of dry matter) } \\
\cline { 2 - 8 } & $\begin{array}{l}\text { 3-O-methyl } \\
\text { rhamnose }\end{array}$ & Rhamnose & Ribose & Mannose & Arabinose & Galactose & Xylose & Glucose \\
\hline Galactose & 1.0 & 0.6 & 4.8 & 11.4 & 1.2 & 49.1 & 4.8 \\
Arabinose & 1.0 & 0.7 & 5.5 & 13.0 & 2.4 & 3.3 & 196.4 \\
Xylose & 1.1 & 0.6 & 7.3 & 12.5 & 1.1 & 3.7 & 9.1 & 10.3 \\
Glucose & 1.1 & 0.7 & 5.5 & 13.2 & 1.1 & 3.7 & 6.4 \\
Rhamnose & 1.2 & 37.6 & 5.7 & 10.3 & ND $^{a}$ & 2.8 & 4.3 \\
\hline
\end{tabular}

${ }^{a} \mathrm{ND}$, Not detected. 
TABLE 6. Molar ratios of reducing sugars in cell walls from cells grown on various carbon sources

\begin{tabular}{|c|c|c|c|c|c|c|c|}
\hline \multirow{2}{*}{$\begin{array}{l}\text { Carbon } \\
\text { source }\end{array}$} & \multicolumn{7}{|c|}{ Molar ratio $^{a}$} \\
\hline & $\begin{array}{l}\text { 3-O-methyl } \\
\text { rhamnose }\end{array}$ & Rhamnose & Mannose & Arabinose & Galactose & Xylose & Glucose \\
\hline Galactose & 2.6 & 2.0 & 0.7 & 1.0 & 1.4 & 3.3 & 4.0 \\
\hline Arabinose & 2.7 & 1.8 & 0.8 & 1.0 & 1.4 & 3.6 & 3.0 \\
\hline Xylose & 3.6 & 1.1 & 0.6 & 1.0 & 1.2 & 3.8 & 2.6 \\
\hline Glucose & 2.6 & 2.2 & 0.8 & 1.0 & 1.4 & 3.6 & 4.4 \\
\hline Rhamnose & 3.5 & 1.2 & 0.7 & 1.0 & 1.2 & 3.1 & 1.8 \\
\hline
\end{tabular}

${ }^{a}$ The level of arabinose was defined as 1.0. Ribose was not detected.

strains of other Catellatospora species and in type strains of species in genera related to Catellatospora.

The cell walls of each strain were purified and hydrolyzed to determine their reducing sugar contents. Clear results were obtained for the strains belonging to the genus Catellatospora. 3-O-methylrhamnose was detected in all of the strains containing MK-10 as the major menaquinone (Catellatospora ferrugine a $6257-\mathrm{C}^{\mathrm{T}}, 6168-\mathrm{B}, 6183-\mathrm{F}, 6248-\mathrm{A}, 6423-$ A, 6432-C, 6464-O, and 6479-B and Catellatospora sp. strain 6393-C). However, this sugar was absent in the strains containing MK-9 (Catellatospora citrea 6183- $\mathrm{E}^{\mathrm{T}}$, 6188-B, 6198-A, 6198-B, 6252-E, and 6479-A, Catellatospora citrea subsp. methionotrophica $6257-\mathrm{B}^{\mathrm{T}}$ and $6498-\mathrm{D}$, and Catellatospora sp. strain 6420-P).

Among the 22 type strains of species in related genera that were tested, no strain contained 3-O-methylrhamnose in its cell walls in a ratio similar to the ratio in the $\mathrm{MK}-10$ containing Catellatospora species. Trace amounts of the sugar were detected in the cell walls of Actinoplanes italicus ATCC $27366^{\mathrm{T}}$, Actinoplanes philippinensis NRRL $5462^{\mathrm{T}}$, Ampullariella lobata ATCC $15350^{\mathrm{T}}$, and Micromonospora purpureochromogenes ATCC $27007^{\mathrm{T}}$. 3-O-methylrhamnose was not detected in the other type strains tested.

Existence of an unknown sugar. An unknown sugar other than 3-O-methylrhamnose was also detected; this sugar was clearly separated during high-performance liquid chromatography from 3-O-methylrhamnose and rhamnose by retention time. It was present in the cell walls of Actinoplanes deccanensis ATCC $21983^{\mathrm{T}}$, Actinoplanes ferrugineus JCM $3277^{\mathrm{T}}$ (= ATCC $29868^{\mathrm{T}}$ ), Actinoplanes philippinensis NRRL $5462^{\mathrm{T}}$, D. matsuzakiense ATCC $31570^{\mathrm{T}}$, and D. thailandense JCM $3084^{\mathrm{T}}\left(=\right.$ ATCC $\left.23490^{\mathrm{T}}\right)$. This sugar was absent in Catellatospora species.

\section{DISCUSSION}

3-O-methylrhamnose has been found in polysaccharides present in planet resins (1), in a freshwater red alga, Batrachospermum (24), and in a lipopolysaccharide from a filamentous blue-green bacterium, Anabaena (27). It has also been reported in glycolipids from Mycobacterium leprae (8, $23)$ and other mycobacterial species $(18,19,26)$, as well as in lipopolysaccharides from species belonging to the genera Klebsiella (4), Rhodopseudomonas $(21,28)$, and Azospirillum (6). It is a component of extracellular capsular polysaccharides of rhizobial root nodules of Acacia $(9,10,12)$ and an antitumor antibiotic, calichemicin, a product of the actinomycete Micromonospora echinospora $(16,17)$.

On the other hand, the form of 3-O-methylrhamnose found in Catellatospora species must be different from the forms found previously, because in Catellatospora species the polymer containing 3-O-methylrhamnose could not be extracted from cell walls by solvents or by boiling in deter- gents. The polymer is bound tightly to peptidoglycan, which means that the polymer must be bound through covalent bonds.

The sugars and amino acids which make up the cell wall play important chemotyping roles in the systematics of actinomycete and coryneform bacteria $(11,14)$. Wall chemotype components depend on their limited distribution in specific genera. Cell wall sugar types can be used to distinguish among genera; e. g., type A (arabinose and galactose) occurs in species of coryneform and nocardioform bacteria, type B (madurose [= 3-O-methyl-D-galactose]) is found in members of genera of the maduromycete group, and type D (xylose and arabinose) occurs in members of genera belonging to the actinoplanate group, while 2- $O$-methyl-D-mannose is a unique key sugar detected in the genus Frankia (20).

3- $O$-methylrhamnose also emphasizes its uniqueness by the fact that it occurs only in MK-10-containing species of the genus Catellatospora. It is localized in the cell walls in a constant ratio despite growth of the cells under different cultural conditions. Moreover, none of the 22 type strains related to Catellatospora species which we tested contained this sugar in a ratio similar to the ratio in Catellatospora species. Only traces of 3-O-methylrhamnose were found in the cell walls of Actinoplanes italicus ATCC $27366^{\mathrm{T}}$, Actinoplanes philippinensis NRRL $5462^{\mathrm{T}}$, Ampullariella lobata ATCC $15350^{\mathrm{T}}$, and Micromonospora purpureochromogenes ATCC $27007^{\mathrm{T}}$. Trace amounts of this sugar are probably not significant in the chemotaxonomy of these strains compared with organisms in which this sugar is present as a major component. The taxonomic significance of 3-O-methylrhamnose is specifically restricted to the genus Catellatospora rather than to all of the chemotype IID actinomycetes.

An unknown sugar other than 3-O-methylrhamnose detected in some strains of the genera Actinoplanes and Dactylosporangium is probably the deoxyhexose reported by Szaniszlo and Gooder (22). It would be interesting to investigate the taxonomic relationships among strains containing this unknown sugar. This sugar was absent in Catellatospora species.

\section{ACKNOWLEDGMENT}

We thank Masumi Asano-Uemura for her skillful technical assistance in various parts of this study.

\section{LITERATURE CITED}

1. Anderson, D. M. W., and A. C. Munro. 1969. Presence of 3-O-methylrhamnose in Araucaria resinous exudates. Phytochemistry 8:633-634.

2. Asano, K., and I. Kawamoto. 1986. Catellatospora, new genus of Actinomycetales. Int. J. Syst. Bacteriol. 36:512-517.

3. Asano, K., and I. Kawamoto. 1988. Catellatospora citrea subsp. methionotrophica subsp. nov., a methionine-deficient auxotroph of the Actinomycetales. Int. J. Syst. Bacteriol. 38:326- 
327.

4. Bjorndal, H., and B. Lindberg. 1970. Structural studies on the lipopolysaccharides from Klebsiella K73:010. Acta Chem. Scand. 24:3414-3415.

5. Bock, K., and C. Pedersen. 1983. Carbon-13 magnetic resonance spectroscopy of monosaccharides. Adv. Carbohydr. Chem. Biochem. 41:27-66.

6. Choma, A., R. Russa, H. Mayer, and Z. Lorkiewicz. 1987. Chemical analysis of Azospirillum lipopolysaccharides. Arch. Microbiol. 146:341-345.

7. Goodfellow, M., and T. Cross. 1984. Classification, p. 7-163. In M. Goodfellow, M. Mordarski, and S. T. Williams (ed.), The biology of the actinomycetes. Academic Press, Inc. (London), Ltd., London.

8. Hunter, S. W., and P. J. Brennan. 1981. A novel phenolic glycolipid from Mycobacterium leprae possibly involved in immunogenicity and pathogenicity. J. Bacteriol. 147:728-735.

9. Jackson, L. K., M. E. Slodki, R. D. Plattner, K. A. Burton, and M. C. Cadmus. 1980. 3-O-methyl-L-rhamnose from a Rhizobium capsular polysaccharide. Carbohydr. Res. 82:154-157.

10. Jackson, L. K., M. E. Slodki, R. D. Plattner, K. A. Burton, and M. C. Cadmus. 1982. Capsular and extracellular polysaccharides from Rhizobium microsymbionts of Acacia decurrens. Carbohydr. Res. 110:267-276.

11. Keddie, R. M., and I. J. Bousfield. 1980. Cell wall composition in the classification and identification of coryneform bacteria, $p$. 167-188. In M. Goodfellow and R. G. Board (ed.), Microbiological classification and identification. Academic Press, Inc. (London), Ltd., London.

12. Kennedy, L. D. 1980 . Rhizobium extracellular polysaccharides: isolation of 6-deoxy- $O$-methyl-hexoses. Carbohydr. Res. 87: 156-160.

13. Lechevalier, H. A., M. P. Lechevalier, and N. N. Gerber. 1971. Chemical composition as a criterion in the classification of actinomycetes. Adv. Appl. Microbiol. 14:47-72.

14. Lechevalier, M. P., and H. A. Lechevalier. 1970. Composition of whole-cell hydrolysates as a criterion in the classification of aerobic actinomycetes, p. 311-316. In H. Prauser (ed.), The Actinomycetales. Gustav Fischer Verlag, Jena, German Democratic Republic.

15. Lechevalier, M. P., A. E. Stern, and H. A. Lechevalier. 1981. Phospholipids in the taxonomy of actinomycetes. Zentralbl. Bakteriol. Parasitenkd. Infektionskr. Hyg. Abt. 1 Suppl. 11: 111p-116p.
16. Lee, M. D., T. S. Dunne, C. C. Chang, G. A. Ellestad, M. M. Siegel, G. O. Morton, W. J. McGahren, and D. B. Borders. 1987. Calichemicins, a novel family of antitumor antibiotics. II. Chemistry and structure of calichemicin $\gamma_{1}$. J. Am. Chem. Soc. 109:3466-3468.

17. Lee, M. D., T. S. Dunne, M. M. Siegel, C. C. Chang, G. O. Morton, and D. B. Borders. 1987. Calichemicins, a novel family of antitumor antibiotics. I. Chemistry and partial structure of calichemicin $\gamma_{1}$. J. Am. Chem. Soc. 109:3464-3465.

18. MacLennan, A. P. 1962. The monosaccharide units in specific glycolipids of Mycobacterium avium. Biochem. J. 82:394-400.

19. MacLennan, A. P., and H. M. Randall. 1961. The occurrence of methyl ethers of rhamnose and fucose in specific glycolipids of certain mycobacteria. Biochem. J. 80:309-318.

20. Mort, A., P. Normand, and M. Lalonde. 1983. 2-O-methyl-Dmannose, a key sugar in the taxonomy of Frankia. Can. J. Microbiol. 29:993-1002.

21. Omar, A. S., H. T. Flammann, D. Borowiak, and J. Weckesser. 1983. Lipopolysaccharides of two strains of the phototrophic bacterium Rhodopseudomonas capsulata. Arch. Microbiol. 134:212-216.

22. Szaniszlo, P. J., and H. Gooder. 1967. Cell wall composition in relation to the taxonomy of some Actinoplanaceae. J. Bacteriol. 96:2037-2047.

23. Tarelli, E., P. Draper, and S. N. Payne. 1984. Structure of the oligosaccharide component of a serologically active phenolic glycolipid isolated from Mycobacterium leprae. Carbohydr. Res. 131:346-352.

24. Turvey, J. R., and L. M. Griffiths. 1973. Mucilage from a fresh-water red alga of the genus Batrachospermum. Phytochemistry 12:2901-2907.

25. Uchida, K., and K. Aida. 1977. Acyl type of bacterial cell wall: its simple identification by colorimetric method. J. Gen. Appl. Microbiol. 23:249-260.

26. Ville, C., and M. Gastambide-Odier. 1970. Le 3-O-méthyl-Lrhamnose, sucre isolé du mycoside $\mathrm{G}$ de Mycobacterium marinum. Carbohydr. Res. 12:97-107.

27. Weckesser, J., A. Katz, G. Drews, H. Mayer, and I. Fromme. 1974. Lipopolysaccharide containing L-acofriose in the filamentous blue-green alga Anabaena variabilis. J. Bacteriol. 120:672678.

28. Weckesser, J., H. Mayer, and G. Drews. 1970. The identification of 3-O-methyl-L-rhamnose as constituent of the lipopolysaccharide of Rhodopseudomonas capsulata. Eur. J. Biochem. 16: 158-160. 